\section{Turf Species Affects Establishment and Growth of Redbud and Pecan}

Jason J. Griffin ${ }^{1,2}$, William R. Reid ${ }^{3}$, and Dale J. Bremer

Department of Horticulture, Forestry and Recreation Resources, Kansas State University, 2021 Throckmorton Plant Science Center, Manhattan, KS 66506

Additional index words. allelopathy, Carya illinoinensis, Cercis canadensis, landscape establishment, mulch

\begin{abstract}
Establishment and growth of eastern redbud (Cercis canadensis L.) and pecan [Carya illinoinensis (Wangenh.) K. Koch] were studied where soil surfaces were either covered with each of three common turfgrass species or maintained free of vegetation by the use of an herbicide or an organic mulch layer. Turf species included two cool-season grasses, tall fescue (Festuca arundinacea Schreb.) and Kentucky bluegrass (Poa pratensis L.), and the warm-season bermudagrass [Cynodon dactylon (L.) Pers.]. After two growing seasons, tree caliper of both species was $100 \%$ greater in turf-free plots compared with trees in the cool-season grass plots. Root weight of pecans increased nearly $200 \%$ when turf was eliminated, and redbud root weight increased nearly $300 \%$. Top weight of redbuds increased $300 \%$ and pecans increased $200 \%$ when turf was eliminated. Total leaf weight of both species was $300 \%$ greater in the turf-free plots, and leaf area increased $\mathbf{2 0 0 \%}$ in both species. Net photosynthesis of redbud trees tended to be higher in the plots without turfgrass, and cool-season grasses inhibited photosynthesis to a greater extent than the warm-season grass. Foliar tissue analysis revealed that nitrogen $(N)$ and potassium (K) were the only elements that increased in concentration when turf was eliminated. However, nutrient concentrations in all treatments were within recommended standard ranges. The results suggest that landscape tree establishment and growth are greatly inhibited by the presence of cool-season turfgrasses and that the inhibition may be more complicated than resource competition.
\end{abstract}

Placing organic mulch over the root system of newly planted trees is common landscape practice. Mulch helps conserve soil moisture, moderate extremes in soil temperature, reduce competition for resources from weeds and turf, and minimize trunk injury due to lawn mowers and string trimmers (Hartman et al., 2000; Lloyd, 1997).

Similar to a natural woodland situation where tree fine roots grow close to the surface, the roots of newly planted, bare-root sugar maple (Acer saccharum Marshall) developed in a similar manner when organic mulch was applied (Green and Watson, 1989). In that report, $40 \%$ of the harvested root density was found in the upper $5 \mathrm{~cm}$ of soils covered with organic mulch. But when covered with turfgrass sod (no mention of grass species), root development was practically nonexistent in the upper $5 \mathrm{~cm}$ and

\footnotetext{
Received for publication 6 June 2006. Accepted for publication 11 Oct. 2006.

This work was funded in part by the Kansas State University Experiment Station.

The authors thank Forrest Keeling Nursery and Williams Lawn Seed for the donation of plant material and Gard'n-Wise Distributors for supplying herbicide and fertilizer products.

${ }^{1}$ To whom correspondence should be addressed; e-mail jgriffin@ksu.edu.

${ }^{2}$ Current address: John C. Pair Horticultural Center, 1901 East 95th St. South, Haysville, KS 67060.

${ }^{3}$ Current address: Pecan Experimental Field, P.O. Box 247, Chetopa, KS 67336
}

overall root production was less than $33 \%$ of the trees that had mulch applied.

Whitcomb (1981) observed that overall growth and appearance of selected woody ornamental species decreased in the presence of bermudagrass (Cynodon dactylon). However, when planted in a $76 \mathrm{~cm}$ square area cleared of bermudagrass, plant growth and appearance was improved. No mulch was applied in that study, which suggests some interference of bermudagrass on establishment and growth of newly planted ornamentals. In contrast, annual shoot and stem caliper growth of honeylocust (Gleditsia triacanthos L.) were similar over two growing seasons between plots covered with bermudagrass and plots with a $60 \mathrm{~cm}$ diameter clearing maintained around the trunks (Khatamian et al., 1984). These studies suggest that the effects of bermudagrass on the establishment and growth of landscape trees is unclear.

Root growth of established trees also benefits from the removal of turfgrass and the addition of mulch. Watson (1988) showed that root density of various 20 -year-old trees increased when sod was replaced with a $10 \mathrm{~cm}$ layer of mulch or simply left as bare soil. The most dramatic response was in the upper $15 \mathrm{~cm}$ of soil, where the density of fine tree roots increased by at least $50 \%$ in all but one species.

Turfgrasses may have an allelopathic effect on woody landscape plants. Recent research has shown that various species of fine fescue (Festuca spp. L.) inhibit seedling growth of large crabgrass [Digitaria sanguinalis (L.) Scop.] and cress (Lepidium sativum L.) (Bertin et al., 2003). In other studies, tall fescue (Festuca arundinacea) inhibited the growth of nearby plants including some trees (Gilmore, 1977; Larson et al., 1995; Peters and Luu, 1985; Smith et al., 2001). Tall fescue is one of the most common turf species used in the landscape industry. Replacing turf with mulch may reduce allelopathic effects on tree establishment and growth. Recent reviews have discussed plant allelopathic interactions and their potential beneficial use in the landscape (Bertin et al., 2003; Weston, 2005; Weston and Duke, 2003).

The objective of the current research was to determine if three common turfgrass species used throughout the southern Great Plains inhibit establishment and growth of eastern redbud (Cercis canadensis) and pecan (Carya illinoinensis). Eastern redbud was selected due to its indeterminate growth habit, common use as a landscape plant, and responsiveness to environmental changes. Pecan was selected because its response to tall fescue sod has been well established in the literature. While the influence of turf on tree establishment has been explored by others, none have examined more than one grass and also included a mulch and bare soil treatment. Additionally, few projects have examined more than one tree species. This report attempts a more expansive look at the influence of turfgrass on landscape tree establishment and growth.

\section{Materials and Methods}

During Fall 2002, 25 individual experimental plots $3 \mathrm{~m} \times 12 \mathrm{~m}$ were established on a Canadian-Waldeck fine sandy loam soil at the John C. Pair Horticultural Center near Wichita, Kans. $\left(37^{\circ} 31^{\prime} \mathrm{N}, 97^{\circ} 19^{\prime}, 380 \mathrm{~m}\right.$ above sea level). On 1 Oct. 2002, all plots were fertilized with $3.3 \mathrm{~kg} \cdot \mathrm{ha}^{-1}$ of $13 \mathrm{~N}-5.7 \mathrm{P}$ $10.7 \mathrm{~K}-3 \mathrm{~S}$. Individual plots were then seeded with one of two cool-season turfgrass species, left bare to be sprigged with a warmseason grass in 2003, mulched with chipped road trimmings to a depth of $7.6 \mathrm{~cm}$, or maintained as a bare soil surface for the duration of the experiment. Mulch was obtained from a local line clearing arborist and consisted of a mixed woody plant species containing wood, bark, and leaves. The two cool-season turf species were 'Kentucky-31' tall fescue seeded at $3.6 \mathrm{~kg} \cdot \mathrm{ha}^{-1}$ and 'Moonlight' Kentucky bluegrass (Poa pratensis) seeded at $1.2 \mathrm{~kg} \cdot \mathrm{ha}^{-1}$. On 27 May 2003, the warm season turf plots were sprigged with transplants of 'Midlawn' bermudagrass at a spacing of $\approx 15 \mathrm{~cm}$. Fertilizer was applied according to local turf or landscape bed recommendations. On an annual basis, cool-season grasses were fertilized with $3.3 \mathrm{~kg} \cdot \mathrm{ha}^{-1}$, and the remaining plots (warmseason grass, mulch, and bare soil) were fertilized with $2.2 \mathrm{~kg} \cdot \mathrm{ha}^{-1}$ of urea $(46 \mathrm{~N}-0 \mathrm{P}-0 \mathrm{~K})$. Dithiopyr (3,5-pyridinedicarbothioic acid, 2-(difluoromethyl)-4-(2-methylpropyl)-6(trifluoromethyl)-S,S-dimethyl ester) was 
applied to all plots each spring for preemergent annual weed control at $2.7 \mathrm{~g} \cdot \mathrm{ha}^{-1}$ a.i.

Uniform seedlings of eastern redbud or pecan, growing in $7.4 \mathrm{~L}$ containers, were obtained from a wholesale liner producer. On 25 Apr. 2003, two trees of each species were transplanted into each field-plot on $3 \mathrm{~m}$ centers so the end trees were $1.5 \mathrm{~m}$ from the plot edge. Overhead irrigation was applied to the entire experimental site at a minimum of $2.5 \mathrm{~cm}$ per week to prevent drought stress. Bare soil and mulched plots were maintained weed free throughout the growing season with spot treatments of $2.0 \%$ Glyphosate ( $N$-(phosphonomethyl)glycine). Throughout the experiment, soil temperature at $10 \mathrm{~cm}$ was recorded using two copper-constantan thermocouples per plot connected to a CR10 datalogger (Campbell Scientific, Logan, Utah). Soil temperature was recorded throughout three complete replications. Temperature was measured every $15 \mathrm{~min}$, and hourly averages were calculated.

Growth data. In Jan. 2004 and Sept. 2004, caliper at $15 \mathrm{~cm}$ above the soil, current season's shoot extension on the three longest shoots, height, canopy width at the widest point (width1), and canopy width perpendicular to the widest point (width2) were measured on each tree. A growth index (GI) was also calculated: (width $1+$ width $2+$ height) $/ 3$.

In Sept. 2004, the experiment was ended and additional growth data were collected. A leaf area meter (LI-3100, LI-COR, Lincoln, Neb.) was used to determine average leaf area of 10 recently matured, randomly selected leaves per plant. All leaves were then removed from each tree and dried for $14 \mathrm{~d}$ at $33^{\circ} \mathrm{C}$. Dried leaves were weighed to determine total leaf dry weight per plant. Stems were severed at the soil interface and dried for $28 \mathrm{~d}$ at $33{ }^{\circ} \mathrm{C}$ to determine total top dry weight (tree aerial portion minus leaves).

The root system of each tree was harvested and weighed. To ensure a consistent soil volume, root systems were harvested with a tree spade (Vermeer TS-44, Pella, Iowa). The redbuds were harvested in a cone of soil $1.12 \mathrm{~m}$ in diameter and a depth of $0.99 \mathrm{~m}$ for a total volume of $0.32 \mathrm{~m}^{3}$. Due to the vertical growth habit of pecan roots, their root systems were dug with a smaller diameter soil cone with a volume of $0.16 \mathrm{~m}^{3}$ (0.89 m diam., $0.79 \mathrm{~m}$ depth). Root systems were washed free of soil and dried similar to the tops to provide root dry weight. Although this method of root harvest did not extract the entire root system, it recovered a majority of the largest roots and provided a consistent sample volume for treatment comparison.

Photosynthesis data. Photosynthesis was measured on each plant during June 2004 and Aug. 2004 using a CIRAS-1 (PP Systems, Haverhill, Mass.) IR gas analyzer. A recently matured leaf was selected at random from the south-facing portion of the tree and placed in the cuvette at $25^{\circ} \mathrm{C}$ with $350 \mu \mathrm{L} \cdot \mathrm{L}^{-1} \mathrm{CO}_{2}$ and irradiance at $1000 \mu \mathrm{mol} \cdot \mathrm{m}^{-2} \cdot \mathrm{s}^{-1} P P F(P P F)$. Assimilation was recorded once carbon exchange stabilized ( $\approx 4 \mathrm{~min})$.
Tissue nutrient analysis. A random sample of dried foliar tissue per plant was analyzed for total $\mathrm{N}$, total $\mathrm{P}, \mathrm{K}, \mathrm{Ca}, \mathrm{Fe}, \mathrm{Mg}$, and $\mathrm{Zn}$ by the Kansas State University Soil Testing Laboratory (Manhattan, Kans.). Total $\mathrm{N}$ and $\mathrm{P}$ were analyzed by the salicylicsulfuric acid digestion as described by Bremner and Mulvaney (1982). Tissue K was analyzed by a sulfuric peroxide digest, described by Linder and Harley (1942) and Thomas et al. (1967). The remaining elements were determined using a perchloric digestion (Gieseking et al., 1935).

Data were analyzed separately for the two tree species using randomized complete block designs. Five treatments per experiment included surfaces surrounding the trunks that were covered with (1) tall fescue; (2) Kentucky bluegrass; (3) bermudagrass; (4) mulch; and (5) bare soil. Each treatment was replicated five times in each of the two experiments. The two subsamples per species were averaged yielding one data point per treatment per block. Data were subjected to ANOVA and means were separated by protected LSD $(P \leq 0.05)$.

\section{Results and Discussion}

By midway through the first growing season, leaf size was visibly larger on trees grown in bare soil and mulch than in turf plots. Additionally, terminal growth of redbuds was indeterminate into October in bare soil or mulch plots, whereas terminal growth of redbuds had stopped by mid-July in turf plots. Although no data were collected, leaves of both tree species growing in the turf plots were chlorotic during most of the growing season compared with the typical dark green color of leaves on trees growing in bare soil or mulch plots. These observations are similar to those of Whitcomb (1981), who noticed a higher plant quality when bermudagrass was cleared from the root zone of newly planted woody landscape plants.

Maximum soil temperatures recorded during this study were greatest in bare soil plots, where no turf or mulch was present to shade the soil surface from solar irradiance (Fig. 1). Diurnal variation in soil temperature among plots was lowest in mulch, and mulch thereby provided the most consistent rhizosphere temperature recorded (data not presented). Diurnal fluctuations in soil temperature under turf plots were intermediate between mulch and bare soil plots; fluctuations under turf were greater than under mulch but lower than in bare soil plots. Soil temperatures recorded during the coldest day of the winter were consistently highest in the mulch treatment (Fig. 2). The insulating effects of mulch and turfgrass, which reduced losses of radiant heat from the soil surface, resulted in higher soil temperatures compared with bare soil plots. Conversely, absence of the insulating effects of mulch or turfgrasses in bare soil plots resulted in lower soil temperatures during winter. Interestingly, bare soil was the only treatment recorded to drop below freezing.
Caliper. At the end of the first growing season, caliper was generally greater in mulched or bare soil than in turf plots, regardless of tree species. Caliper of redbuds growing in mulch was greater than any of those growing in turf (Table 1). Redbuds growing in bare soil had a caliper greater than any of the trees growing in the cool season grasses but not significantly greater than the trees in the bermudagrass.

By the end of the second growing season, caliper of the redbuds growing in bare soil or mulch was nearly 2 -fold greater than either of the cool-season grasses. These results agree with previous reports of a 2 -fold increase in caliper of newly planted sugar maples in mulch compared with turf (Green and Watson, 1989). Caliper of the trees growing in bermudagrass plots was also greater than either of the cool-season grasses but less than bare soil or mulch plots. The dormancy characteristics of bermudagrass, a warmseason grass, may explain its intermediate effects on tree caliper. During peak tree root activity, bermudagrass is either dormant or only partially active. Therefore, there is potentially less direct competition for resources. This may also explain why Khatamian et al. (1984) reported no influence of bermudagrass on caliper of newly planted honeylocust. In the current report, bermudagrass limited growth of redbuds compared with mulched and bare plots but to a much lesser degree than the cool-season grasses.

Caliper of the pecan trees was significantly greater in the mulch and bare soil plots compared with the turf plots after the first growing season (Table 2). There was no difference after one growing season among the turf plots. After two growing seasons, however, pecan trees growing in fescue had the smallest caliper. These data support findings of others that pecan tree growth is reduced when surrounded by tall fescue (Smith et al., 2000, 2002). After two growing seasons, caliper was similar between the bare soil and the mulch plots. As was true with the redbuds, caliper of pecan trees in the turf plots was greatest in the bermudagrass.Height and shoot extension.

After one growing season, height was similar for either tree species in either treatment (Tables 1 and 2). Following the second growing season, the height of redbuds in the mulched plots was greater than in either of the cool-season grasses; redbud heights remained similar among bare soil and turfgrass treatments. Tree height of the pecan trees remained similar among treatments at the end of the second year.

In both years, shoot extension of the three longest shoots among redbuds was generally greater on trees in bare soil or mulch plots, while shoot extension was the least on trees in the cool season grasses (Table 1). Shoot extension of pecan trees, however, was not significantly affected by treatments in either year (Table 2). Although mean shoot extension of pecan trees in mulch and bare soil plots was more than two times greater than in fescue plots, high variability among plots 


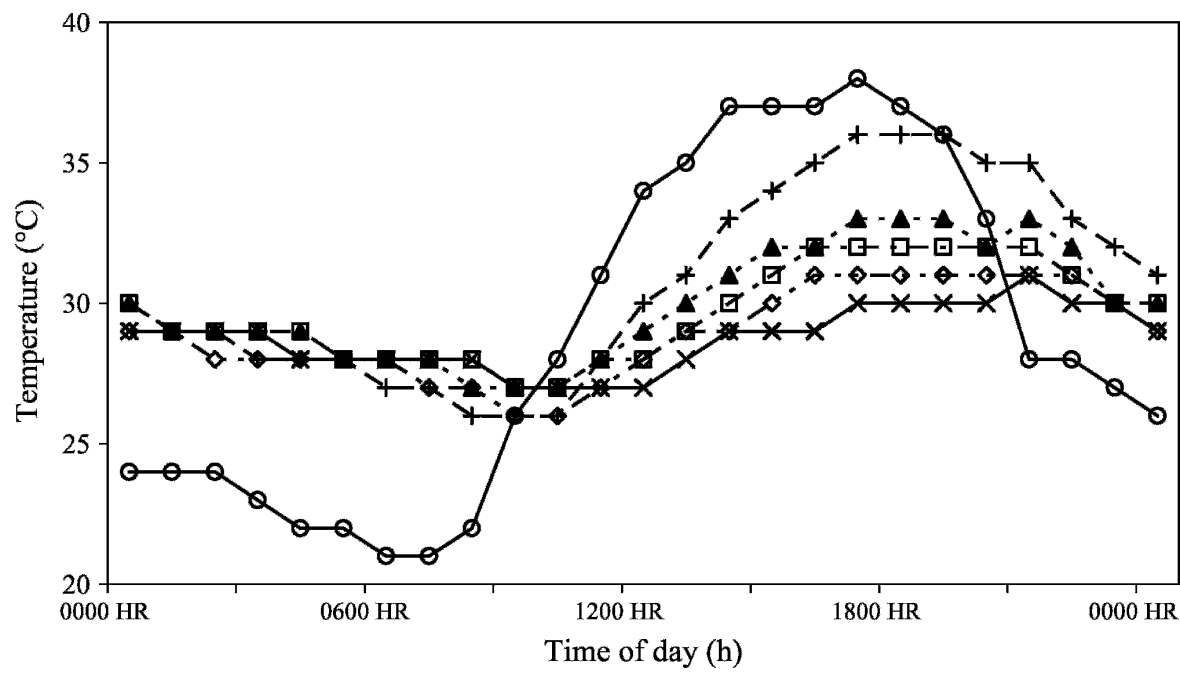

Fig. 1. Ambient air temperature measured $1.2 \mathrm{~m}$ above the soil surface and soil temperature measured $10 \mathrm{~cm}$ below the surface on the warmest day of 2003 (Aug. 24): bare soil (+), Kentucky bluegrass ( $\boldsymbol{\Delta}$ ), bermudagrass $(\square)$, tall fescue $(\diamond)$, mulch $(\times)$, and ambient $(\bigcirc) ; n=3$.

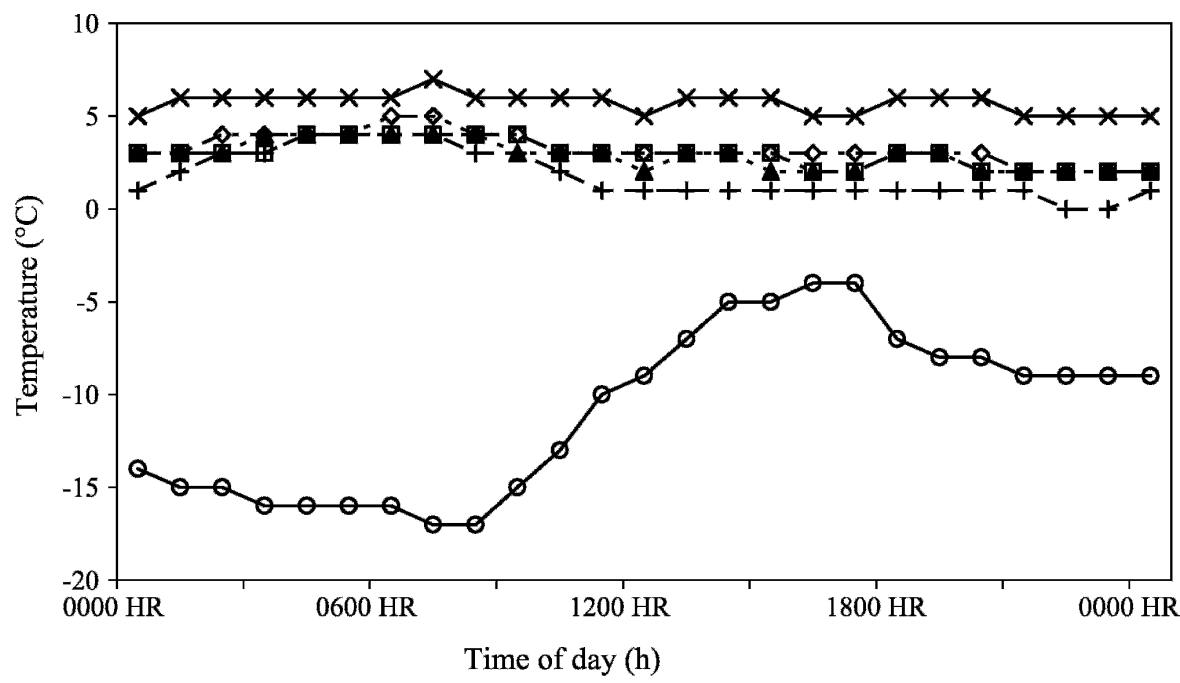

Fig. 2. Ambient air temperature measured $1.2 \mathrm{~m}$ above the soil surface, and soil temperature measured $10 \mathrm{~cm}$ below the surface on the coldest day of the 2003-2004 winter season (6 Jan. 2004): soil (+), Kentucky bluegrass $(\boldsymbol{\Delta})$, bermudagrass $(\square)$, tall fescue $(\diamond)$, mulch $(\times)$, and ambient $(\bigcirc) ; \mathrm{n}=3$.

Table 1. Stem caliper, height, shoot extension, and growth index (GI) of redbud trees growing under various soil surface treatments; data were collected after the growing seasons of 2003 (Year 1) and 2004 (Year 2)

\begin{tabular}{|c|c|c|c|c|c|c|c|c|}
\hline \multirow[b]{2}{*}{ Treatment } & \multicolumn{2}{|c|}{ Stem caliper $(\mathrm{cm})$} & \multicolumn{2}{|c|}{ Height (m) } & \multicolumn{2}{|c|}{ Shoot extension $(\mathrm{cm})$} & \multicolumn{2}{|c|}{$\mathrm{GI}^{\mathrm{z}}$} \\
\hline & Yr 1 & Yr 2 & Yr 1 & Yr 2 & Yr 1 & Yr 2 & Yr 1 & Yr 2 \\
\hline Mulch & $2.7 \mathrm{a}^{\mathrm{y}}$ & $5.2 \mathrm{a}$ & 1.7 & $1.87 \mathrm{a}$ & $96.3 \mathrm{a}$ & $87.0 \mathrm{a}$ & $1.6 \mathrm{a}$ & $2.3 \mathrm{a}$ \\
\hline Bare soil & $2.5 \mathrm{ab}$ & $4.8 \mathrm{a}$ & 1.6 & $1.77 \mathrm{ab}$ & $79.0 \mathrm{ab}$ & $87.4 \mathrm{a}$ & $1.3 \mathrm{ab}$ & $2.2 \mathrm{a}$ \\
\hline Bermudagrass & $2.0 \mathrm{bc}$ & $3.5 \mathrm{~b}$ & 1.5 & $1.74 \mathrm{ab}$ & $50.6 \mathrm{bc}$ & $41.5 \mathrm{~b}$ & $1.1 \mathrm{bc}$ & $1.5 \mathrm{~b}$ \\
\hline K. bluegrass & $1.7 \mathrm{~cd}$ & $2.6 \mathrm{c}$ & 1.5 & $1.64 \mathrm{~b}$ & $36.2 \mathrm{c}$ & $28.8 \mathrm{bc}$ & $0.9 \mathrm{c}$ & $1.2 \mathrm{~b}$ \\
\hline Fescue & $1.5 \mathrm{~d}$ & $2.1 \mathrm{c}$ & 1.6 & $1.65 \mathrm{~b}$ & $30.8 \mathrm{c}$ & $14.6 \mathrm{c}$ & $1.0 \mathrm{c}$ & $1.1 \mathrm{~b}$ \\
\hline ANOVA & $* *$ & $* *$ & NS & $* *$ & $* *$ & $* *$ & $* *$ & $* *$ \\
\hline
\end{tabular}

${ }^{\mathrm{z}} \mathrm{GI}=($ width $1+$ width $2+$ height $) / 3$

${ }^{\mathrm{y}}$ Mean separation within a column by Fisher's protected LSD $(P \leq 0.05) ; \mathrm{n}=10$. Means followed by the same letter within a column are not significantly different.

Ns, **Nonsignificant or significant at $P<0.01$

resulted in differences that were insignificant. In both tree species (albeit insignificantly in pecans), fescue appeared to be the most inhibitory because trees grew less than half in the second year as they did in the first. This suggests an increase in competitiveness or perhaps in allelopathic properties of fescue as it aged, which may have increasingly affected trees as their roots extended beyond the original container substrate.
Despite greater shoot extension of redbuds in bare soil and mulch than in turf plots, tree height was less affected (Table 1). Because of the rapid growth of redbud shoots in bare soil and mulch plots, the individual branches lacked the rigidity to grow upright and assumed an arching growth habit. Conversely, the relatively short shoot extension of redbuds in turf plots allowed the branches to remain rigid and maintain an upright growth habit. As a result, shoot extension of trees in turf contributed more to vertical growth, whereas shoot extension of trees in bare soil and mulch plots contributed more to canopy width and little to vertical height. Consequently, the GI was calculated to integrate measurements of tree height and canopy width and thus, to more comprehensively quantify overall tree growth.

Growth index. In the first season, GIs of redbuds were lower in all three turfgrasses than in the mulch treatment (Table 1). The GIs of redbuds were also lower in both coolseason turfgrasses than in bare soil, although GIs were similar between bare soil and bermudagrass. By the end of the second growing season, the effects were more pronounced, with redbuds in all three turfgrasses having significantly lower GIs than in bare soil or mulch; thus, all three turfgrasses apparently inhibit redbud tree growth. Pecan trees had a greater GI in mulch than in the cool-season grasses after one growing season (Table 2). After two growing seasons, however, no significant differences in pecan GIs remained among treatments although trends were similar to the first year.

Dry weights. After two growing seasons, root dry weight of redbuds was greatest in mulch and bare soil, and the root weight of pecans was greater in mulch than in any of the turfgrasses (Table 3). The smallest root weights of redbuds were in the cool-season grasses, while in pecans the smallest root weights were in all three turfgrasses. Root systems of both tree species were 4- to 5-fold greater in plots with no turf than in the fescue plots. In fescue plots, root growth of trees was inhibited to the point that the original container root system was clearly visible upon excavation, whereas in all other plots there were no visual signs of the container root system. Relative growth of tree root systems is often modeled by measuring stem caliper. Therefore, it is not surprising that the root dry weights followed a similar pattern to stem caliper. Both redbud caliper and root dry weight were greatest in the non-turfgrass plots and smallest in the cool-season turfgrass plots (Tables 1 and 3 ).

Top dry weights of the both species were reduced by cool season turfgrasses (Table 3 ). Top dry weights of redbuds were greatest in mulch and bare soil and least in turfgrasses. Top dry weights of redbuds in nonturf plots were more than twice as great as in bermudagrass, and five to nearly nine times greater than in cool-season grasses. Top dry weight of pecan trees from smallest to largest was nearly a 4-fold difference with top dry weight in bare soil greater than either turf plot. 
Table 2. Stem caliper, height, shoot extension, and growth index (GI) of pecan trees growing under various soil surface treatments; data were collected after the growing seasons of 2003 (Year 1) and 2004 (Year 2).

\begin{tabular}{|c|c|c|c|c|c|c|c|c|}
\hline \multirow[b]{2}{*}{ Treatment } & \multicolumn{2}{|c|}{ Stem caliper $(\mathrm{cm})$} & \multicolumn{2}{|c|}{ Height (m) } & \multicolumn{2}{|c|}{ Shoot extension $(\mathrm{cm})$} & \multicolumn{2}{|c|}{$\mathrm{GI}^{\mathrm{z}}$} \\
\hline & Yr 1 & Yr 2 & Yr 1 & Yr 2 & Yr 1 & Yr 2 & Yr 1 & Yr 2 \\
\hline$\overline{\text { Mulch }}$ & $1.3 \mathrm{a}^{\mathrm{y}}$ & $2.3 \mathrm{a}$ & 0.75 & 1.0 & 26.9 & 23.2 & $0.36 \mathrm{a}$ & 0.55 \\
\hline Bare soil & $1.3 \mathrm{a}$ & $2.2 \mathrm{a}$ & 0.77 & 1.1 & 28.4 & 26.6 & $0.34 \mathrm{ab}$ & 1.30 \\
\hline Bermudagrass & $1.1 \mathrm{~b}$ & $1.8 \mathrm{~b}$ & 0.67 & 0.8 & 27.0 & 17.3 & $0.34 \mathrm{ab}$ & 0.54 \\
\hline K. bluegrass & $1.1 \mathrm{~b}$ & $1.5 \mathrm{bc}$ & 0.71 & 0.8 & 27.7 & 13.9 & $0.31 \mathrm{bc}$ & 0.42 \\
\hline Fescue & $1.1 \mathrm{~b}$ & $1.3 \mathrm{c}$ & 0.70 & 0.7 & 23.7 & 9.9 & $0.29 \mathrm{c}$ & 0.32 \\
\hline ANOVA & $*$ & $* *$ & NS & NS & NS & NS & $* *$ & NS \\
\hline
\end{tabular}

${ }^{\mathrm{z}} \mathrm{GI}=($ width $1+$ width $2+$ height $) / 3$.

${ }^{\mathrm{y}}$ Mean separation within a column by Fisher's protected LSD $(P \leq 0.05) ; \mathrm{n}=10$. Means followed by the same letter within a column are not significantly different.

Ns, ****Nonsignificant or significant at $P<0.05$, or 0.01 , respectively.

Table 3. Root dry weight, top dry weight (leaves excluded), and root: top ratio of redbud and pecan trees growing under various soil surface treatments; data were collected after the growing season of Year 2 (2004).

\begin{tabular}{|c|c|c|c|c|c|c|}
\hline \multirow[b]{2}{*}{ Treatment } & \multicolumn{2}{|c|}{ Root wt (g) } & \multicolumn{2}{|c|}{ Top wt (g) } & \multicolumn{2}{|c|}{ Ratio of root/top } \\
\hline & Redbud & Pecan & Redbud & Pecan & Redbud & Pecan \\
\hline$\overline{\text { Mulch }}$ & $1978 \mathrm{a}^{\mathrm{z}}$ & $589 \mathrm{a}$ & $2614 \mathrm{a}$ & $172 \mathrm{ab}$ & $0.8 \mathrm{~b}$ & 2.4 \\
\hline Bare soil & $2231 \mathrm{a}$ & $489 a b$ & $2383 \mathrm{a}$ & $256 \mathrm{a}$ & $1.1 \mathrm{~b}$ & 2.7 \\
\hline Bermudagrass & $1261 \mathrm{~b}$ & $314 \mathrm{bc}$ & $1077 \mathrm{~b}$ & $112 \mathrm{bc}$ & $1.3 \mathrm{ab}$ & 2.9 \\
\hline K. bluegrass & $671 \mathrm{c}$ & $253 \mathrm{bc}$ & $424 \mathrm{~b}$ & $86 \mathrm{bc}$ & $1.7 \mathrm{a}$ & 2.9 \\
\hline Fescue & $494 \mathrm{c}$ & $111 \mathrm{c}$ & $299 \mathrm{~b}$ & $53 \mathrm{c}$ & $1.7 \mathrm{a}$ & 2.0 \\
\hline ANOVA & $* *$ & $* *$ & $* *$ & $* *$ & $* *$ & NS \\
\hline
\end{tabular}

${ }^{\mathrm{z}}$ Mean separation within a column by Fisher's protected LSD $(P \leq 0.05) ; \mathrm{n}=10$. Means followed by the same letter within a column are not significantly different.

Ns,**Nonsignificant or significant at $P<0.01$.

The root/top (R:T) ratio of redbuds in Kentucky bluegrass and fescue was larger than in mulch or bare soil plots (Table 3), indicating a relatively larger root system in relation to the top portion of the plant in the presence of cool-season turfgrass. The R:T of trees in bermudagrass was similar to all other treatments. The R:T of pecan trees was unaffected by the treatments. However, the values of R:T of pecans was larger than that of redbuds. This suggests that on a relative scale, pecan trees may allocate more energy to root than to top production compared with redbuds, in the first few years of establishment at least. This may explain why in the current study differences in pecan growth are observed on measurements related to root growth (caliper and root dry weight) and fewer treatment effects are observed on top growth measurements (height, shoot extension, top dry weight, and leaf dry weight).

Total leaf weight of redbud trees was similar between mulch and bare soil but was substantially reduced by the presence of turf (Table 4). Pecan leaf weight was also greater in the mulched or bare soil plots and smallest in the cool-season turfgrass plots. Leaf weight of pecan growing in the fescue plots was only $8 \%$ to $10 \%$ of that in bare soil or mulch plots. Similarly, leaf area of redbud trees was greatest when trees were growing in mulch or bare soil (Table 4). Leaf area on trees growing in turf plots were about half as large. Leaf area of the pecan trees followed exactly the same trend.

Photosynthesis. Net photosynthesis of pecan trees was unaffected by treatment at either the June or August date (11.7 and 14.4 $\mu \mathrm{mol} \cdot \mathrm{m}^{-2} \cdot \mathrm{s}^{-1}$, respectively). However, net photosynthesis of the redbud trees was influenced by the treatments (Table 5). During the June measurement, when all trees were actively growing, the bare soil and bermudagrass treatments had the highest rates of photosynthesis. By mid-August, the redbud trees in the Kentucky bluegrass and fescue treatments had stopped growing, whereas trees in the other treatments were actively producing new leaves. During the August measurement, the bare soil and mulch treatments had the highest rates of photosynthesis, which might be attributed to higher foliar $\mathrm{N}$ concentration (Table 6). Interestingly, photosynthesis in the bermudagrass treatment was similar to the mulch and bare soil treatment in June but was the lowest rate in August.

Tissue nutrient analysis. Nutrient analyses of redbud foliage revealed treatment effects for $\mathrm{N}, \mathrm{P}, \mathrm{K}, \mathrm{Ca}, \mathrm{Mg}$, and $\mathrm{Zn}$ (Table $6)$; treatments did not affect $\mathrm{Fe}$ content of tissue. Nitrogen content of tissue was greater in mulch and bare soil than in turf plots. However, there was only a $0.3 \%$ difference in foliar $\mathrm{N}$ between the fescue plots, which had the poorest growth, and the mulch plots, which had the greatest caliper, height, and GI. Additionally, all of the $\mathrm{N}$ values are within the sufficiency range of $1.14 \%$ to $2.86 \%$ reported for redbud trees growing in a field production nursery and botanical garden setting (Mills and Jones, 1996). Foliar $\mathrm{P}$ of redbud was greatest in the turf plots and lowest in the mulch and bare soil plots. Again, all $\mathrm{P}$ concentrations were within the recommended sufficiency range of $0.09 \%$ to $0.82 \%$. Tissue concentration of $\mathrm{K}$ was greatest in the redbud trees growing in the
Table 4. Total leaf dry weight and leaf area of typical recently matured leaf of redbud and pecan trees growing under various soil surface treatments; data were collected after the growing season of Year 2 (2004).

\begin{tabular}{lcccccc}
\hline & \multicolumn{2}{c}{$\begin{array}{c}\text { Leaf wt }(\mathrm{g}) \\
\end{array}$} & & \multicolumn{2}{c}{$\begin{array}{c}\text { Leaf area } \\
\left(\mathrm{cm}^{2}\right)^{\mathrm{z}}\end{array}$} \\
\cline { 2 - 3 } \cline { 6 - 7 } Treatment & Redbud & Pecan & & Redbud & Pecan \\
\hline Mulch & $882 \mathrm{a}^{\mathrm{y}}$ & $99 \mathrm{a}$ & & $106.3 \mathrm{a}$ & $313 \mathrm{a}$ \\
Bare soil & $931 \mathrm{a}$ & $82 \mathrm{a}$ & & $109.8 \mathrm{a}$ & $249 \mathrm{a}$ \\
Bermudagrass & $330 \mathrm{~b}$ & $39 \mathrm{ab}$ & & $69.1 \mathrm{~b}$ & $147 \mathrm{~b}$ \\
K. bluegrass & $143 \mathrm{~b}$ & $22 \mathrm{~b}$ & & $53.9 \mathrm{~b}$ & $135 \mathrm{~b}$ \\
Fescue & $97 \mathrm{~b}$ & $8 \mathrm{~b}$ & & $46.1 \mathrm{~b}$ & $97 \mathrm{~b}$ \\
ANOVA & $* *$ & $*$ & & $* *$ & $* *$ \\
\hline
\end{tabular}

${ }^{\mathrm{z} A v e r a g e}$ of 10 recently matured leaves per plant; $\mathrm{n}=100$ per treatment.

${ }^{y}$ Mean separation within a column by Fisher's protected LSD $(P \leq 0.05)$. Means followed by the same letter within a column are not significantly different.

$*, * *$ Significant at $P<0.05$ or 0.01 , respectively.

Table 5. Net photosynthesis of redbud trees growing under various soil surface treatments; data were collected on 23 June 2004 and 18 Aug. 2004 (Year 2).

\begin{tabular}{lll}
\hline Treatment & \multicolumn{1}{c}{ June } & August \\
\hline Mulch & $14.2 \mathrm{abc}^{\mathrm{z}}$ & $17.5 \mathrm{ab}$ \\
Bare soil & $17.8 \mathrm{a}$ & $19.7 \mathrm{a}$ \\
Bermudagrass & $16.6 \mathrm{ab}$ & $12.5 \mathrm{~d}$ \\
K. bluegrass & $10.9 \mathrm{c}$ & $16.0 \mathrm{bc}$ \\
Fescue & $12.9 \mathrm{bc}$ & $13.2 \mathrm{~cd}$ \\
ANOVA & $*$ & $* *$ \\
\hline
\end{tabular}

"Mean separation within a column by Fisher's protected LSD $(P \leq 0.05)$. Means followed by the same letter within a column are not significantly different.

$*, * *$ Significant at $P<0.05$ or 0.01 , respectively.

mulched plots, all other treatments were within the sufficiency range of $0.76 \%$ to $1.43 \%$. The remaining nutrients were all within the sufficiency ranges and generally tended to be greater in trees growing in turf than the trees in mulch or bare soil. Nutrient analysis of the redbud foliage indicates that only $\mathrm{N}$ was present in greater concentration in the trees growing in mulch and bare soil, and that difference was less than $0.5 \%$. Since $\mathrm{N}$ concentration across all treatments were within the recommended range, it is unlikely that $\mathrm{N}$ concentrations are responsible for the magnitude of the growth responses observed.

Nutrient analysis of pecan foliage revealed treatment effects for $\mathrm{N}, \mathrm{P}, \mathrm{K}, \mathrm{Ca}$, and $\mathrm{Mg}$, but not for $\mathrm{Fe}$ or $\mathrm{Zn}$ (Table 7). However, Zn concentration below 50 ppm indicates a deficiency for pecan production and suggests the trees growing in mulch and bare soil plots were lacking Zn. As with the redbud, $\mathrm{N}$ concentration was greatest in pecan trees growing in mulch or bare soil and least in trees growing in turf. There was no treatment effect among the turfgrasses. Foliar $\mathrm{N}$ concentration of the trees growing in mulch and bare soil were within the sufficiency range reported by Mills and Jones (1996). However, these values are lower than a commonly reported concentration of $2.5 \%$ for regularly fertilized trees (Smith, 1991; 
Table 6. Foliar nutrient content of redbud grown for two seasons under various soil surface treatments.

\begin{tabular}{lcccccc}
\hline & \multicolumn{5}{c}{ Treatment } \\
\cline { 2 - 6 } Nutrient & Mulch & Bare soil & Bermuda & K. bluegrass & Fescue & ANOVA \\
\hline $\mathrm{N}(\%)$ & $2.1 \mathrm{a}^{\mathrm{z}}$ & $2.3 \mathrm{a}$ & $1.7 \mathrm{~b}$ & $1.6 \mathrm{~b}$ & $1.8 \mathrm{~b}$ & $* *$ \\
$\mathrm{P}(\%)$ & $0.39 \mathrm{c}$ & $0.31 \mathrm{c}$ & $0.56 \mathrm{~b}$ & $0.58 \mathrm{~b}$ & $0.73 \mathrm{a}$ & $* *$ \\
$\mathrm{~K}(\%)$ & $1.12 \mathrm{a}$ & $0.91 \mathrm{bc}$ & $0.97 \mathrm{~b}$ & $0.84 \mathrm{c}$ & $0.96 \mathrm{bc}$ & $* *$ \\
$\mathrm{Ca}(\mathrm{ppm})$ & $26338 \mathrm{c}$ & $26188 \mathrm{c}$ & $30135 \mathrm{~b}$ & $35707 \mathrm{a}$ & $32132 \mathrm{~b}$ & $* *$ \\
$\mathrm{Mg}(\mathrm{ppm})$ & $2684 \mathrm{~b}$ & $3144 \mathrm{~b}$ & $2807 \mathrm{~b}$ & $3692 \mathrm{a}$ & $3164 \mathrm{~b}$ & $*$ \\
$\mathrm{Fe}(\mathrm{ppm})$ & 209 & 244 & 229 & 205 & 247 & NS \\
Zn (ppm) & $14.8 \mathrm{~b}$ & $15.2 \mathrm{~b}$ & $17.3 \mathrm{ab}$ & $20.8 \mathrm{a}$ & $19.2 \mathrm{a}$ & $*$ \\
\hline
\end{tabular}

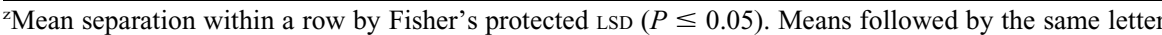
within a row are not significantly different.

NS, $*, * *$ Nonsignificant or significant at $P<0.05$, or 0.01 , respectively.

Table 7. Foliar nutrient content of pecan grown for two seasons under various soil surface treatments.

\begin{tabular}{lcccccc}
\hline & \multicolumn{5}{c}{ Treatment } \\
\cline { 2 - 5 } Nutrient & Mulch & Bare soil & Bermuda & K. bluegrass & Fescue & ANOVA \\
\hline $\mathrm{N}(\%)$ & $2.1 \mathrm{a}^{\mathrm{z}}$ & $2.2 \mathrm{a}$ & $1.7 \mathrm{~b}$ & $1.5 \mathrm{~b}$ & $1.6 \mathrm{~b}$ & $* *$ \\
$\mathrm{P}(\%)$ & $0.27 \mathrm{c}$ & $0.24 \mathrm{c}$ & $0.37 \mathrm{~b}$ & $0.40 \mathrm{~b}$ & $0.56 \mathrm{a}$ & $* *$ \\
$\mathrm{~K}(\%)$ & $0.93 \mathrm{a}$ & $0.77 \mathrm{~b}$ & $0.74 \mathrm{bc}$ & $0.63 \mathrm{c}$ & $0.82 \mathrm{ab}$ & $* *$ \\
$\mathrm{Ca}(\mathrm{ppm})$ & $25550 \mathrm{~d}$ & $27186 \mathrm{~cd}$ & $29926 \mathrm{bc}$ & $34689 \mathrm{a}$ & $32425 \mathrm{ab}$ & $* *$ \\
$\mathrm{Mg}(\mathrm{ppm})$ & $2690 \mathrm{c}$ & $3218 \mathrm{~b}$ & $3197 \mathrm{~b}$ & $3913 \mathrm{a}$ & $3233 \mathrm{~b}$ & $* *$ \\
$\mathrm{Fe}(\mathrm{ppm})$ & 237 & 289 & 247 & 210 & 234 & NS \\
Zn (ppm) & 40.8 & 33.8 & 87.0 & 105.8 & 106.2 & NS \\
\hline
\end{tabular}

${ }^{\mathrm{z}}$ Mean separation within a row by Fisher's protected LSD $(P \leq 0.05)$. Means followed by the same letter within a row are not significantly different.

NS, $* *$ Nonsignificant or significant at $P<0.01$.

Smith et al., 2000, 2002, 2004; Worley, 1997). Therefore, nitrogen deficiency may have been partly responsible for reduced growth of pecan under turfgrass. Foliar P concentration was affected by the treatments and, similar to the redbud, was greatest in the trees growing in turf. In all treatments, $\mathrm{P}$ concentration was well above the minimum sufficiency level suggested by Smith (1991). The concentration of $\mathrm{K}$ was also influenced by the treatments although no clear trend was observed between the turf and nonturf plots. Trees in bare soil, bermudagrass and Kentucky bluegrass were at, or slightly below the minimum foliar $\mathrm{K}$ sufficiency range (Smith, 1991). Both Ca and $\mathrm{Mg}$ were within the sufficiency range (Mills and Jones, 1996) and were greater in trees growing in turf than the bare soil or mulch plots; foliar $\mathrm{Mg}$ in mulch was below the minimum sufficiency range suggested by Smith (1991).

In the current study, the presence of turfgrass reduced overall tree growth. Experimental plots were managed according to current landscape recommendations regarding irrigation and fertilization. While competition for water and nutrients may have played a role in tree growth, photosynthesis data does not suggest strong resource competition. Under conditions of water and nutrient shortage, photosynthesis would be reduced correspondingly. Photosynthesis of pecan trees was unaffected by the treatments, and photosynthesis of redbuds did not follow the pattern defined by growth data. Addition-
Gilmore, A.R. 1977. How fescue (Festuca arundinaceae) inhibits growth of sweetgum trees Liquidamber styraciflua. Ill. Res. 19:8-9.

Green, T.L. and G.W. Watson. 1989. Effects of turfgrass and mulch on the establishment and growth of bare-root sugar maples. J. Arb. 15:268-272.

Hartman, J.R., T.P. Pirone, and M.A. Sall. 2000. Pirone's tree maintenance. 7th ed. Oxford University Press, New York.

Khatamian, H., J.C. Pair, and R. Carrow. 1984. Effects of turf competition and fertilizer application on trunk diameter and nutrient composition of honeylocust. J. Arb. 10:156-159.

Larson, M.M., S.H. Patel, and J.P. Vimmerstedt. 1995. Allelopathic interactions between herbaceous species and trees grown in topsoil and spoil media. J. Sustain. For. 3(1):39-52.

Linder, R.C. and C.P. Harley. 1942. A rapid method for the determination of nitrogen in plant tissue. Science 96:565-566.

Lloyd, J. 1997. Plant health care for woody ornamentals. Printec Press, Champaign, Ill.

Mills, H.A. and J.B. Jones, Jr. 1996. Plant analysis handbook. II. MicroMacro Publishing, Athens, Ga.

Peters, H.C. and K.T. Luu. 1985. Allelopathy in tall fescue, pp. 273-283. In: A.C. Thompson (ed.). Chemistry of allelopathy: biochemical interactions among plants. ACS, Washington, D.C.

Smith, M.W. 1991. Pecan nutrition. In: B.W. Wood and J.A. Payne (eds.). Pecan husbandry: challenges and opportunities. 1st National Pecan Workshop Proc., USDA-ARS Pub ARS-96. $259 \mathrm{pp}$.

Smith, M.W., B.L. Carroll, and B.S. Cheary. 2000. Mulch improves pecan tree growth during orchard establishment. HortScience 35:192195.

Smith, M.W., B.S. Cheary, and B.L. Carroll. 2002. Fescue sod suppresses young pecan tree growth. HortScience 37:1045-1048.

Smith, M.W., B.S. Cheary, and B.L. Carroll. 2004. Response of pecan to nitrogen rate and nitrogen application time. HortScience 39:14121415 .

Smith, M.W., M.E. Wolf, B.S. Cheary, and B.L. Carroll. 2001. Allelopathy of bermudagrass, tall fescue, redroot pigweed, and cutleaf evening primrose on pecan. HortScience 36 : 1047-1048.

Thomas, R.L., R.W. Sheard, and J.R. Moyer. 1967. Comparison of conventional and automated procedures for nitrogen, phosphorus, and potassium analysis of plant material using a single digestion. Agron. J. 59:240-243.

Bertin, C., R.N. Paul, S.O. Duke, and L.A. Weston. 2003. Laboratory assessment of the allelopathic effects of fine leaf fescues. J. Chem. Ecol. 29:1919-1937.

Bertin, C., X. Yang, and L.A. Weston. 2003. The role of root exudates and allelochemicals in the rhizosphere. Plant Soil 256:67-83.

Bremner, J.M. and C.S. Mulvaney. 1982. Salicylic acid thiosulfate modification of the Kjeldahl method to include nitrate and nitrite. p. 621. In: R.H. Miller and D.R. Keeney (eds.). Methods of soil analysis. Part 2. Am. Soc. Agron., Inc., Madison, Wis.

Gieseking, J.E., H.J. Snider, and C.A. Getz. 1935. Destruction of organic matter in plant material by the use of nitric and perchloric acids. Ind. Eng. Chem. Anal. Ed. 7:185-186.
Watson, G.W. 1988. Organic mulch and grass competition influence tree root development. J. Arb. 14:200-203.

Weston, L.A. 2005. History and current trends in the use of allelopathy for weed management. HortTechnology 15:529-534.

Weston, L.A. and S.O. Duke. 2003. Weed and crop allelopathy. Crit. Rev. Plant Sci. 22:367389 .

Whitcomb, C.E. 1981. Response of woody landscape plants to bermudagrass competition and fertility. J. Arb. 7:191-194.

Worley, R.E. 1997. Nineteen years of ammonium nitrate application to limited areas is not detrimental to pecans. HortScience 32:79-81. 